\title{
CORRELATION OF ARMY ALPHA INTELLIGENCE TEST WITH ACADEMIC GRADES IN HIGH SCHOOLS AND MILITARY ACADEMIES
}

\author{
By H E. Burtr and G. F. ARPs, Ohio State University
}

\section{Introduction}

Numerous studies have been made in recent years comparing mental tests, and especially intelligence tests with academic grades. The underlying hope seems to be that a student with good mental ability or intelligence (original nature) will do well in school or college and receive good marks and that, hence, it will be possible to predict future academic status on the basis of tests which measure intelligence. One of the most notable results of practically all such studies is the low correlation obtained. A correlation of .50 seems to be the exception rather than the rule, and prediction based on a correlation much smaller than this is of doubtful value in the individual case

There are at least two errors which might contribute to these low correlations: either the tests are not an accurate measure of mental ability or the school marks are not an accurate measure of academic ability. Either measure is of course vitiated if the work is not performed with maximum incentive. It is probable that most pupils work with a fair approach to their maximum ability in taking mental tests. The test is usually brief and does not reach the point of producing "annoyingness" as is often done by school work. Furthermore the pupil being unaware of the real purpose of the tests assumes that a good deal is at stake and, consequently, does his best It is probable on the other hand that many students do not work with maximum incentive in their studies. or do not devote to them sufficient time to manifest their maximum ability. Any teacher would heartily endorse this statement. The writers feel that this latter alternative is a possible explanation of the low correlations generally found between intelligence tests and academic status. Suggestions of this sort have been made before. ${ }^{1}$ It would seem further that certain types of instruction hold students more closely than

$x$ Anderson, J. E, Intelligence Tests of Yale Freshmen, School and Society, Vol XI, $417-420$ 
other types to their maximum intellectual ability One of the writers found a noticeably closer relation between the adult "point scale" (Yerkes) and grades of students in a psychology course which had frequent and vigorous written examinations than between point scale and total academic marks for a similar group. ${ }^{2}$

During the summer of 1918 one of the writers was in charge of the mental examination of a group of R. O. T. C. men at Camp Custer, Michigan. Most of the members of the group were at the time in the midst of their course in high schools or military acadenies. These two types of institution differ considerably in methods of instruction especially with respect to supervision of study, general supervision of pupils and systems of demerit (punishment). It seemed possible by comparing the intelligence tests and academic marks for those groups to determine whether the methods of instruction do differ in the extent to which they elicit maximum intellectual performance in school.

\section{Method}

Academic marks prior to army service were obtained from the heads of schools and academies which these R. O. T. C. men had previously attended. The information was obtained on a blank calling for the average mark of a student in science, mathematics, languages (including English), history and "other subjects" and also the number of courses of each sort that were taken. Most of the marks obtained were in numerical form so that statistical treatment was possible. It was an easy matter to obtain a single average for total academic work by weighting each branch of study in proportion to the number of courses taken in that branch.

It is obvious that marks obtained from different schools with their different standards of marking could not be validly grouped together in crude form to obtain a correlation coefficient. Even if the marks were thrown in to terms of average or passing mark there would still be a source of error in the scatter for different schools. Consequently, each school or academy was taken separately and the mean and standard deviation obtained for total academic marks of the R. O. T. C. men of that school and the mean and standard deviation found also for the various school branches for those same men. Each individual mark was then put in the form of $X$

2 Yerkes, R. M. and Burtt, H. E. The Relation of Point Scale Measurements of Intelligence to Educational Performance in College Students School and Society, Vol. V, 535-540. 
divided by standard deviation where $\mathrm{X}$ is deviation from the mean. Thus a student with a score of +1.5 in school $A$ is of the same academic ability as a student with a score of +1.5 in school $\mathrm{B}$, although the passing mark and the scatter of the students in the two schools are entirely different. The score simply indicates what proportion of the standard deviation for this school the person is above or below the average for this school. Scores of this sort were then available for all the features of interest, and it was valid to include all the military students in one group and the high school students in another. No school was included from which there were fewer than ten R. O. T. C. men. These scores were then plotted against the Army Alpha Intelligence Test and the correlation computed by the products-moments method.

\section{Results}

The correlations are based on 118 men in five military academies and 93 men in eight high schools. The groups themselves are very sinilar in intelligence as shown by the test. The military academy group has a mean score of 129 and a standard deviation of 25.6 , while the high school group has a mean score of 130 and a standard deviation of 25.8 . The principal interest lies in the comparative correlations for the two groups These are given in the tables.

\begin{tabular}{|c|c|c|c|}
\hline \multicolumn{4}{|c|}{ TABLE I } \\
\hline \multicolumn{2}{|c|}{$\begin{array}{l}\text { Correlation Alpha } \\
\text { Total With: }\end{array}$} & $\begin{array}{l}\text { Military } \\
\text { Academies }\end{array}$ & $\begin{array}{l}\text { High } \\
\text { Schools }\end{array}$ \\
\hline $\begin{array}{l}\text { Academic total } \\
\text { Mathematics } \\
\text { Science. . } \\
\text { Language.. } \\
\text { History... . }\end{array}$ & $\cdot$ & $\begin{array}{l}39 \\
.32 \\
.47 \\
42 \\
40\end{array}$ & $\begin{array}{l}.19 \\
.16 \\
18 \\
.22 \\
25\end{array}$ \\
\hline P. E. (Approximate) & . & 05 & .07 \\
\hline \multicolumn{4}{|c|}{ TABLE II } \\
\hline \multicolumn{2}{|c|}{$\begin{array}{l}\text { Correlation Academic } \\
\text { Total With. }\end{array}$} & $\begin{array}{l}\text { Military } \\
\text { Academies }\end{array}$ & $\begin{array}{l}\text { High } \\
\text { Schools }\end{array}$ \\
\hline $\begin{array}{l}\text { Test } 1 \ldots . \\
\text { Test } 2 . \\
\text { Test } 3 \\
\text { Test } 4 \\
\text { Test } 5 \\
\text { Test } 6 \\
\text { Test } 7 . \quad \ldots \\
\text { Test } 8\end{array}$ & $\dot{ }$ & $\begin{array}{l}41 \\
36 \\
19 \\
41 \\
32 \\
25 \\
45 \\
25\end{array}$ & $\begin{array}{r}06 \\
.14 \\
27 \\
.27 \\
26 \\
.16 \\
18 \\
37\end{array}$ \\
\hline P. E. (Approximate) & & 06 & 08 \\
\hline
\end{tabular}


Table 1 gives the correlation of the total Alpha score, that is the general intelligence rating, with the total academic marks and also with marks in several school branches. The correlations are of about the same order that is usually found in similar studies. The most noticeable thing in the table is the correlation of intelligence and total academic ability of .39 for the military group as contrasted with .19 for the high school group. This is a most significant result of the study. The writers feel that it indicates a superiority of methods of instruction in military academies from the stand point of holding the students to their maximum mental efficiency. This result does not seem to be due primarily to any single school subject The difference between the correlation for the two groups holds rather consistently with various school subjects as indicated in the other figures of the table. The difference seems to be slightly greater with science and slightly less with history but it is very doubtful if this fact is of significance. It is impossible that the discrepancy between the two groups could be due to a greater homogeneity of the high school group in intelligence because the standard deviations show that the distribution curves of the two groups are practically identical.

Table 2 gives the correlation of total academic marks with the eight different tests of the Alpha Examination. This table is not as significant as the first. There are two tests, 3 (practical judgment) and 8 (information) in which the correlations are slightly higher for the high school group but the differences are not significant when the P.E. is considered. The greatest discrepancies in the other direction are in test I (directions) and test 7 (analogies). This would suggest that these latter tests are somewhat more indicative of the instruction differential between the two types of school.

It seemed worth while to investigate the linearity of the regression in the case of the two principal correlations of the study. The correlation ratio (eta) was found to be .52 for academic total on Alpha total in the military group and .49 in the high school. The corresponding correlation coefficients were .39 and .19 Blakeman $^{3}$ suggests several formulae which give the ratio of the difference between eta and $r$, or of the difference between their squares to the probable error. His simpler formula (recommended for rough work) gives a value of 2.8 for the military regression and 3.2 for the high

${ }^{3}$ Blakeman, J. On Tests for Linearity of Regression in Frequency Distributions. Biometrike, Vol. 4, 332-350. 
school. His more exhaustive formulae, (one giving ratio of difference of squares to probable error and the other giving ratio of difference of first powers to probable error) agree closely in yrelding values of 3.0 and 3.9 for the respective groups. B Blakeman considers that this value should be less than 2.5 (corresponding to a probability of 9 to 1 ) to indicate linearity.

These figures indicate that for the high school regression at least the observed values fit some curve more closely than they fit a straight line. Inspection of the scatter plot suggests a considerable concentration in the quadrant for high intelligence and low academic grades and the possibility of the regression line curving somewhat in to that quadrant. Many of the individuals in this quadrant are doubtless those who have good ability but are not induced to use it in school. This feature is not nearly as clear in an inspection of the plot for military students and furthermore Blakeman's test shows this regression to be more nearly linear. These facts are a further corroboration of the main thesis of this study.

\section{Conclusion}

The low correlation generally found between intelligence tests and academic marks may be to a considerable extent due to the fact that methods of school instruction do not hold students to their maximum efficiency. The correlation of Army Alpha with academic marks in high schools and military academies yields an appreciably higher correlation for the latter group. This is not caused by differences in homogenity of the groups nor does not seem due primarily to any special school subject but to be a general characteristic throughout the curriculum. This suggests that methods of instruction in the military academy, such as general supervision, supervised study and a system of reward and punishment, are more apt to hold the student to his maximum intellectual ability. 